\title{
KARAKTERISTIK DAN POLA PENGOBATAN PADA PASIEN PEDIATRI PENDERITA ISPA DI PUSKESMAS REMAJA SAMARINDA
}

\author{
Redemptus Patria Adeliriansyah, Victoria Yulita F, Arsyik Ibrahim \\ Fakultas Farmasi Universitas Mulawarman, Samarinda, Kalimantan Timur \\ Redemptus_patria@yahoo.co.id
}

\begin{abstract}
ABSTRAK
Infeksi Saluran Pernafasan Atas (ISPA) adalah infeksi yang mengenai struktur saluran pernafasan diatas laring yang disebabkan oleh infeksi bakteri maupun virus. Penyakit ISPA merupakan penyakit yang sering menyerang masyarakat dan menempati urutan pertama penyebab kematian pada kelompok bayi dan balita. Penelitian ini bertujuan untuk mengetahui karakteristik dan pola pengobatan ISPA yang diberikan pada pasien pediatri. Penelitian ini bersifat prospektif yang menggunakan kuisioner yang telah divalidasi untuk mengambil data dari pasien anak yang didiagnosa ISPA. Jumlah pasien yang diteliti sebanyak 15 pasien. Berdasarkan hasil penelitian, jumlah pasien perempuan $80 \%$, laki-laki $20 \%$, balita $53 \%$, anak-anak $47 \%$, pekerjaan orang tua IRT $73 \%$, pendidikan orang tua SMA sederajat $73 \%$. Berdasarkan diagnosis dibagi menjadi 4 kelompok yaitu sinusitis akut (J01) 6,5\%, faringitis akut (J02) 6,5\%, tonsilitis akut (J03) 60\%, dan ISPA tidak spesifik (J069) 27\%. Pola ketepatan pengobatan pemberian antibiotik untuk kategori J01 dan J02 $100 \%$ tidak tepat, kategori J03 55,56\% tepat dan 44,44\% tidak tepat, kategori J069 100\% tidak tepat dengan golongan antibiotik yang digunakan adalah golongan makrolida dan turunan penisilin. obat penunjang yang diberikan adalah kortikosterid, ß2-agonist, mukolitik, antihistamin, analgesik-antipiretik, ekspektoran, vitamin. Berdasarkan hasil yang didapatkan dapat disimpulkan, setiap pasien ISPA pediatrik akan diberi 2 terapi yaitu terapi antibiotik dan terapi penunjang.
\end{abstract}

Kata kunci : ISPA, karakteristik pasien, Pola pengobatan

\begin{abstract}
Upper Respiratory Track Infection (URTI) is an infection that affects the structure of the respiratory tract above the larynx caused by a bacter infants and toddlers group. This study aims to determine the characteristics and management of treatment URTI for pediatric. This study is a prospective, using a questionnaire that has been validated to retrieve data from patient. Total of patients to be studied are 15 patients. Based on the results of the study, the number of male patients are $80 \%$ of female, $20 \%$ male, baby $53 \%$, children $47 \%$, parents's job as wife are $73 \%$, parent educated of Senior high school are $73 \%$. Based on the diagnosis, it divided into four groups namely acute sinusitis (J01) 6.5\%, acute pharyngitis (J02) 6.5\%, acute tonsillitis (J03) 60\% and URTI not specific (J069) 27\%. The precision of Management for group J01 and J02 are 100\% incorrect, for group J03 are $55,56 \%$ correct and 44,44\% incorrect, and for category J069 is $100 \%$ incorrect with antibiotic theraphy used are class of macroliede and penicilin derivatives. Adjuvant theraphy that has been given are corticosterid, B2-agonist, mucolitic, antihistamine, analgesic-antipyretic, ekspectoran, vitamin. Based on the results it can be concluded, each
\end{abstract}


URTI pediatrict patient will be given 2 therapy that are antibiotic therapy and adjuvant therapy.

Key Word: URTI, characteristics patient, management of treatment

\section{PENDAHULUAN}

Infeksi pada saluran napas merupakan penyakit yang umum terjadi pada masyarakat. Infeksi Saluran Pernapasan Atas (ISPA) adalah proses infeksi akut pada saluran pernafasan bagian atas yang disebabkan oleh mikroorganisme. Umumnya, penyebab dari infeksi saluran napas adalah berbagai mikroorganisme, Namun yang terbanyak yakni dikarenakan infeksi virus dan bakteri. ${ }^{1}$

Di Indonesia, ISPA selalu menempati urutan pertama penyebab kematian pada kelompok bayi dan balita. Selain itu ISPA juga sering berada pada daftar 10 penyakit terbanyak di rumah sakit. Survei mortalitas yang dilakukan oleh Subdit ISPA, menempatkan ISPA sebagai penyebab kematian bayi terbesar di Indonesia dengan persentase 22,30\% dari seluruh kematian balita.

Menurut Riskesdas (2007) prevalensi nasional ISPA adalah 25,50\%. Sebanyak 16 provinsi mempunyai prevalensi ISPA di atas prevalensi nasional, yaitu Nusa Tenggara Timur (41,36\%), Nanggroe Aceh Darusalam (36,64\%), Papua Barat (36,20\%), Gorontalo $(33,99 \%)$, Papua (30,56\%), Maluku (30,40\%), Bangka Belitung (30,32\%), Bengkulu (29,84\%), Jawa Tengah (29,08\%), Banten (28,39\%), Sulawesi Tengah (28,36\%), Kalimantan Timur (27,52\%), Kalimantan Selatan (27,06\%), Nusa Tenggara Barat (26,52\%), Sumatera Barat (26,38\%), dan Kepulauan Riau (25,78\%).

Penatalaksanaan pada penyakit ISPA atas mencangkup pemberian antibiotik dan pengobatan imtomatis. Pemberian antibiotik pada pasien ISPA bagian atas didasarkan pada pedoman pemberian antibiotik yang mencangkup beberapa pertimbangan antara lain diagnosis, gejala klinis, pemeriksaan fisik, dan hasil dari pemeriksaan penunjang. Antibiotik diberikan apabila penyakit ISPA bagian atas tersebut disebabkan oleh infeksi bakteri. Adanya penggunaan antibiotik yang tidak rasional dapat memberikan efek negatif, antara lain meningkatkan pembiayaan pengobatan, meningkatkan resistensi, serta meningkatkan kemungkinan efek samping ${ }^{2}$

Tingginya pravalensi kejadian ISPA di indonesia dengan terapi pengobatannya menggunakan abtibiotik menimbulkan suatu permasalahan yaitu kesesuaian pola penggunaan antibiotika untuk pengobatan ISPA. Penelitian ini bertujuan untuk mengetahui karakteristik dan pola pengobatan ISPA yang diberikan pada pasien anak di Puskesmas Remaja

\section{METODE PENELITIAN}

Penelitian ini merupakan penelitian prospektif yang bersifat deskriptif kualitatif. Penelitian dilakukan dengan cara memberi kuisioner kepada pasien berdasarkan kuisioner yang telah divalidasi dan melakukan wawancara pada pasien selama pengobatan.

Populasi adalah pasien yang berobat di Puskesmas Remaja Samarinda. Sampel yang digunakan adalah pasien-pasien penderita ISPA yang berobat pada Puskesmas Remaja Samarinda. Sampel penelitian yang termasuk dalam kriteria inklusi adalah semua pasien penderita ISPA pada bulan Maret 2016 sampai dengan April 2016, bersedia menjadi responden penelitian, Pasien dengan umur dibawah 12 tahun, pasien ISPA dengan penggunaan antibiotik dan bertempat tinggal di wilayah tempat objek penelitian.

Teknik pengambilan sampel yang digunakan adalah tenik non-random dengan metode Quota sampling pada pasien ISPA sesuai dengan kriteria inklusi yang datang ke 
Puskesmas Remaja. Pengambilan data dilakukan dengan pemberian kuisioner dan wawancara kepada pasien yang didiagnosa ISPA pada Puskesmas Remaja. Data yang diambil pada pasien adalah jenis kelamin, usia, pekerjaan orang tua, tingkat pendidikan orang tua, dan jenis obat yang diberikan.

\section{HASIL DAN PEMBAHASAN}

\section{Karakteristik}

\section{a. Karakteristik berdasarkan jenis kelamin}

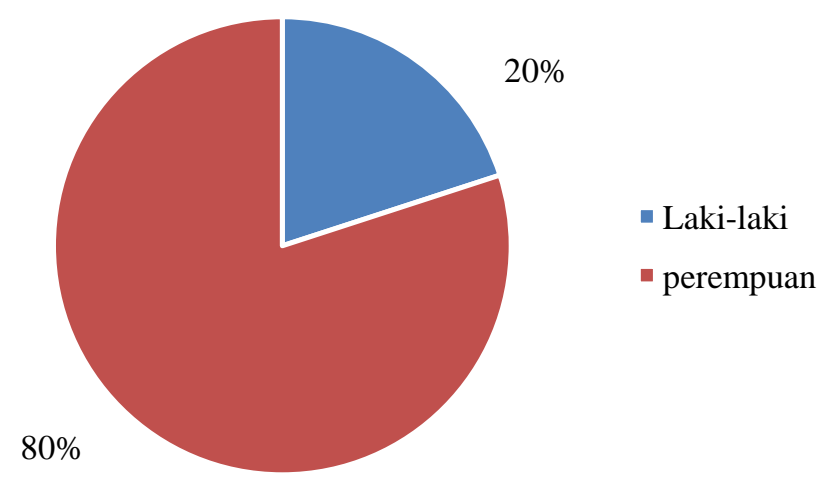

Gambar 1. Karkteristik pasien berdasarkan jenis kelamin

Berdasarkan data diatas dapat dilihat bahawa pasien anak penderita ISPA di Puskesmas Remaja Samarinda yang paling banyak adalah dengan jenis kelamin perempuan yaitu sebesar $80 \%$ (12 pasien) dan diikuti dengan laki-laki sebesar 20\% (3 pasien). Menurut hasil penelitian Nur, H. (2004) menunjukkan bahwa tidak ada hubungan yang bermakna antara jenis kelamin dengan kejadian ISPA ${ }^{3}$.

\section{b. Karakteristik berdasarkan usia}

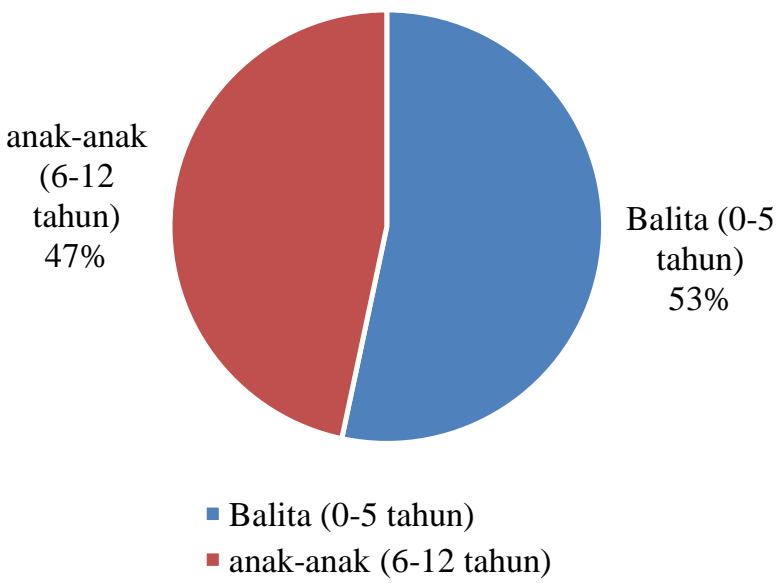

Gambar 2. Karkteristik pasien berdasarkan usia 
Berdasarkan data diatas dapat dilihat bahwa pasien anak penderita ISPA di Puskesmas Remaja Samarinda yang paling banyak adalah balita sebesar 53\% (8 pasien) dan diikuti oleh anak-anak 47\% (7 pasien). Hal ini disebabkan karena pada balita sistem imunitas tubuhnya belum sempurna jika dibandingkan dengan anak-anak. Hal inilah yang membuat balita rentan terjangkit penyakit ISPA

\section{c. Karakteristik berdasarkan pekerjaan orang tua}

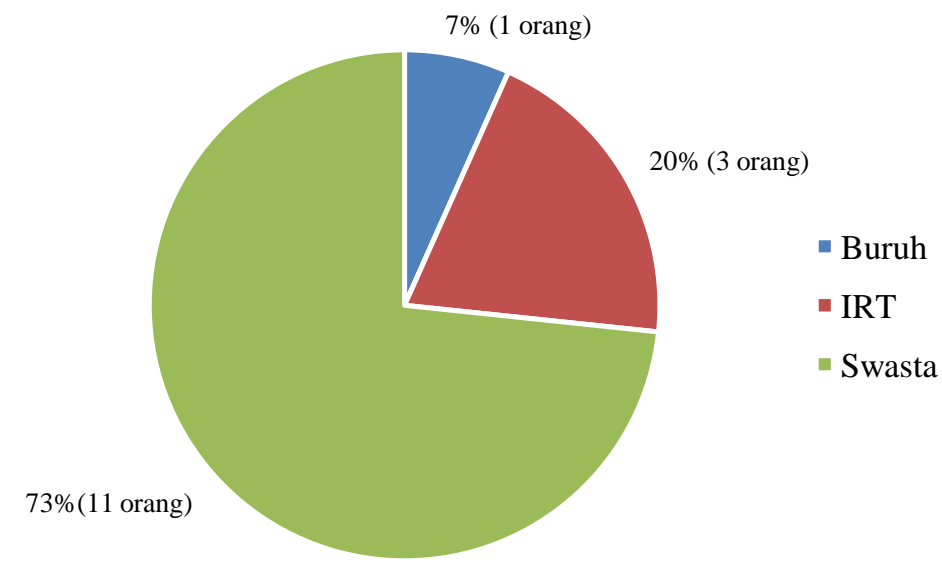

Gambar 3. Karkteristik pasien berdasarkan pekerjaan orang tua

Berdasarkan data diatas dapat dilihat bahwa pasien anak penderita ISPA di Puskesmas Remaja Samarinda yang paling banyak adalah dengan pekerjaan orang tua IRT sebesar 73\% (11 pasien) lalu swasta sebesar 20\% (3 pasien) dan buruh sebesar 7\% (1 pasien). Pekerjaan dengan tingkat penghasilan yang rendah menyebabkan orang tua sulit menyediakan fasilitas perumahan yang baik, perawatan kesehatan dan gizi anak yang memadai. Rendahnya kualitas gizi anak menyebabkan daya tahan tubuh berkurang dan mudah terkena penyakit infeksi

\section{d. Karakteristik berdasarkan tingkat pendidikan orang tua}

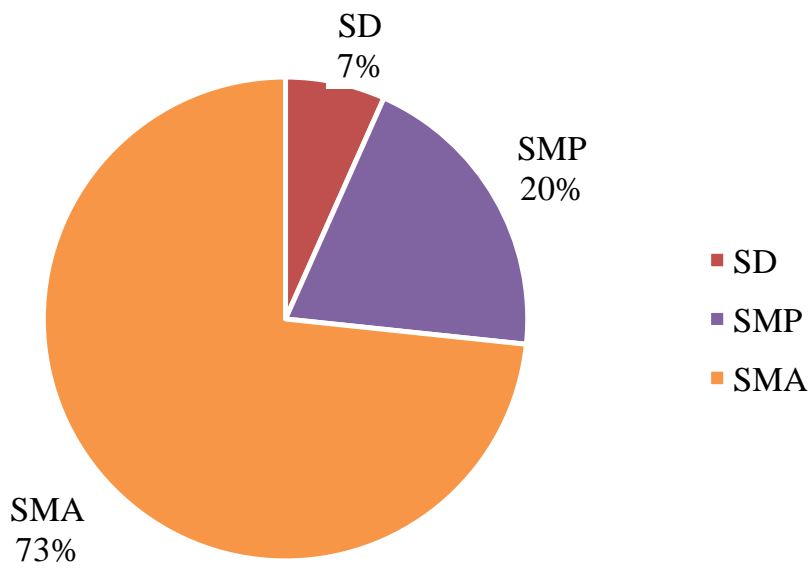

Gambar 4. Karakteristik pasien berdasarkan pendidikan orang tua 
Berdasarkan data gambar 4 dapat dilihat bahwa pasien anak penderita ISPA di Puskesmas Remaja Samarinda yang paling banyak adalah pasien dengan orang tua berpendidikan SMA sederajat 73\% (11 pasien), lalu SMP sebesar 20\% (3 pasien), dan SD sebesar 7\% (1 pasien). Orang tua yang memiliki pendidikan yang lebih tinggi pada umumnya memiliki pengetahuan yang lebih luas, sehingga dapat lebih mudah dalam menyerap dan menerima informasi serta aktif berperan serta dalam mengatasi masalah kesehatannya dan keluarganya. Saran dan pesan kesehatan yang disampaikan oleh berbagai media atau petugas kesehatan akan mudah dimengerti oleh orang tua yang berpendidikan tinggi dibandingkan orang tua dengan tingkat pendidikan rendah.

\section{Pola Pengobatan}

Dari 15 sampel yang didiagnosa ISPA, dapat dibedakan menjadi 4 sub penyakit yaitu Sinusitis akut (J01) 1 orang, Faringitis akut (J02) 1 orang, Tonsilitis akut (J03) 9 orang, ISPA akut tidak spesifik (J069) 4 orang.

\section{a. Sinusitis akut (J01)}

Tabel 1. Pola pengobatan pada pasien J01 berdasarkan literatur berbanding hasil penelitian

\begin{tabular}{ccccccc}
\hline & \multicolumn{2}{c}{ Literatur } & \multicolumn{2}{c}{ Hasil Penelitian } & & \\
\cline { 2 - 5 } & Pasien baru & Pasien berlanjut & Pasien baru & Pasien berlanjut & & $\boldsymbol{\Sigma}$ \\
\hline Obat Lini pertama & Amoxicilin & - & - & - & 0 & 0 \\
Obat Lanjutan & - & Eritromicin & Eritromicin & - & 1 & 100 \\
& - & Azitromicin & - & - & 0 & 0 \\
& - & Claritomicin & - & - & 0 & 0 \\
\hline
\end{tabular}

Tabel 2. Obat-obat penunjang yang diberikan pada pasien J01

\begin{tabular}{cccc}
\hline Nama Obat & Kegunaan & Jumlah pasien & Persentase \\
\hline Dexametason & kortikosteroid & 1 & $100 \%$ \\
CTM $^{*}$ & Antihistamin & 1 & $100 \%$ \\
Salbutamol & Bronkodilator & 1 & $100 \%$ \\
Ambroxol & Mukolitik & 1 & $100 \%$ \\
\hline
\end{tabular}

*CTM (Chlorpheniramine maleat)

Sinusitis adalah infeksi atau peradangan pada sinus paranasal mukosa yang disebabkan oleh bakteri ataupun virus. Bakteri yang paling sering menyebabkan sinusitis adalah $S$. pneumoniae dan $H$. Influenzae. Berdasarkan Tabel 1, sebanyak $100 \%$ pasien J01 (Sinusitis Akut) diberikan eritromicin sebagai obat lini pertama, hal ini tidak sesuai dengan teori. Menurut AJ Brink (2008), lini pertama untuk pengobatan sinusitis akut adalah amoxicillin dan lini selanjutnya adalah eritromicin, azitromicin, dan claritomicin. Eritromicin, azitromicin, dan claritomicin digunakan untuk mengobati pasien dengan alergi terhadap beta-laktam. Sedangkan amoxicillin merupakan antibiotika spektrum luas dan pilihan antibiotika utama sebelum hasil kultur keluar. Berdasarkan Tabel 2, obat-obatan yang 
menunjang pengobatan J01 adalah dexametason, CTM, salbutamol, ambroxol. Dexametason digunakan untuk mengurangi oedema subglotis dengan cara menekan proses inflamasi lokal, CTM merupakan antihistamin yang bekerja dengan cara memblokir reseptor-histamin (H1-reseptor blokers) sehingga dapat mencegah efek bronkokonstriksi, ambroxol merupakan obat yang dipakai untuk mengencerkan mukus yang kental sehingga mudah untuk dikeluarkan dan salbutamol bekerja dengan cara mendilatasi bronkus dan bronkiolus yang akan meningkatkan aliran udara.

\section{b. Faringitis akut (J02)}

Tabel 3. Pola pengobatan pada pasien J02 berdasarkan literatur berbanding hasil penelitian

\begin{tabular}{ccccccc}
\hline & \multicolumn{2}{c}{ Literatur } & \multicolumn{2}{c}{ Hasil Penelitian } & \\
\cline { 2 - 5 } & Pasien baru & $\begin{array}{c}\text { Pasien } \\
\text { berlanjut }\end{array}$ & Pasien baru & $\begin{array}{c}\text { Pasien } \\
\text { berlanjut }\end{array}$ & \multirow{2}{*}{$\boldsymbol{\%}$} \\
\hline Obat Lini pertama & Penicilin VK* & - & - & - & 0 & $0 \%$ \\
Obat Lanjutan & - & Eritromicin & Eritromicin & - & 1 & $100 \%$ \\
& - & Azitromicin & - & - & 0 & $0 \%$ \\
& - & Claritomicin & - & - & 0 & $0 \%$ \\
\hline
\end{tabular}

* Phenoxymethylpenicillin pottasium

Tabel 4. Obat-obat penunjang yang diberikan pada pasien J02

\begin{tabular}{cccc}
\hline Nama Obat & Kegunaan & Jumlah pasien & Persentase \\
\hline Dexametason & Kortikosteroid & 1 & $100 \%$ \\
CTM $^{*}$ & Antihistamin & 1 & $100 \%$ \\
PCT $^{*}$ & Analgesik & 1 & $100 \%$ \\
GG* $_{\text {Antasida }}^{*}$ & Ekspektoran & 1 & $100 \%$ \\
GG(Gliseril Guaiakolat); PCT(Parasetamol); CTM (Chlorpheniramine maleat)
\end{tabular}

Faringitis adalah infeksi akut pada orofaring atau nasofaring yang umumnya disebabkan oleh virus. Bakteri utama penyebab penyakit ini adalah group A $\beta$-hemolytic Streptococcus atau S. pyogenes. Berdasarkan Tabel 3, sebanyak $100 \%$ pasien J02 diberikan eritromicin sebagai obat lini pertama. Hal ini tidak sesuai dengan teori. Menurut AJ Brink (2008), penicillin VK digunakan sebagai obat lini pertama dan lini selanjutnya adalah eritromicin, azitromicin, dan claritomicin. Eritromicin, azitromicin, dan claritomicin digunakan untuk mengobati pasien yang alergi terhadap beta-laktam. Berdasarkan Tabel 4, obat-obatan yang menunjang pengobatan J02 adalah dexametason, CTM, dan PCT. PCT digunakan sebagai Analgesik antipiretik untuk mengurangi gejala malaise, letargi, dan demam terkait sistem pernafasan. 


\section{c. Tonsilitis akut (J03)}

Tabel 5. Pola pengobatan pada pasien J03 berdasarkan literatur berbanding hasil penelitian

\begin{tabular}{|c|c|c|c|c|c|c|}
\hline & \multicolumn{2}{|c|}{ Literatur } & \multicolumn{2}{|c|}{ Hasil Penelitian } & \multirow[b]{2}{*}{$\Sigma$} & \multirow[b]{2}{*}{$\%$} \\
\hline & Pasien baru & $\begin{array}{c}\text { Pasien } \\
\text { berlanjut }\end{array}$ & Pasien baru & $\begin{array}{c}\text { Pasien } \\
\text { berlanjut }\end{array}$ & & \\
\hline Obat Lini & Amoxicilin & - & Amoxicilin & - & 5 & $55,56 \%$ \\
\hline pertama & Penicilin & - & - & - & 0 & $0 \%$ \\
\hline Obat Lanjutan & - & Eritromicin & Eritromicin & - & 4 & $44,44 \%$ \\
\hline
\end{tabular}

Tabel 6. Obat-obat penunjang yang diberikan pada pasien J03

\begin{tabular}{cccc}
\hline Nama Obat & Kegunaan & Jumlah Pasien & Presentase \\
\hline Ambroxol & Mukolitik & 5 & $55,56 \%$ \\
PCT $^{*}$ & Analgesik & 7 & $77,78 \%$ \\
CTM $^{*}$ & Antihistamin & 6 & $66,67 \%$ \\
Dexametason & Kortikosteroid & 9 & $100 \%$ \\
Bromhexine HCL & Mukolitik & 2 & $22,22 \%$ \\
Antasida & Penetral asam lambung & 1 & $11,11 \%$ \\
Vitamin B complex & Vitamin & 1 & $11,11 \%$ \\
\hline *PCT(Parasetamol); CTM (Chlorpheniramine maleat)
\end{tabular}

*PCT(Parasetamol); CTM (Chlorpheniramine maleat)

Tonsilitis adalah peradangan tonsil palatina yang merupakan bagian dari cincin waldeyer yang disebabkan oleh kuman Streptococcus $\beta$-hemolyticus, Streptococcus viridans dan Streptococcus pyogenes, serta dapat juga disebabkan oleh virus Berdasarkan Tabel 5, sebanyak 55,56\% pasien J03 diberikan amoxicilin sebagai obat lini pertama. Dan 44,44\% diberikan eritromicin sebagai lini pertama. Menurut WCDHB (2013) penicillin dan amoxicillin digunakan sebagai obat lini pertama dan lini selanjutnya adalah eritromicin. Eritromicin digunakan untuk mengobati pasien dengan alergi terhadap beta-laktam. Sedangkan penisilin dan turunannya merupakan antibiotika spectrum luas dan pilihan antibiotika utama sebelum hasil kultur keluar. Berdasarkan Tabel 6, obat-obatan yang menunjang pengobatan J03 adalah dexametason, CTM, ambroxol, bromhexine HCL dan PCT. bromhexine HCL merupakan obat golongan mukolitik yang dipakai untuk mengencerkan mukus yang kental sehingga mudah untuk dikeluarkan.

\section{d. ISPA akut tidak spesifik (J069)}

Tabel 7. Pola pengobatan pada pasien J069 berdasarkan literatur berbanding hasil penelitian

\begin{tabular}{cccccc}
\hline \multicolumn{2}{c}{ Literatur } & \multicolumn{2}{c}{ Hasil Penelitian } & \multirow{2}{*}{$\boldsymbol{\%}$} \\
\cline { 1 - 4 } Pasien baru & Pasien berlanjut & Pasien baru & Pasien berlanjut & & \\
\cline { 1 - 4 } & - & Amoxicilin & - & & $100 \%$ \\
\hline
\end{tabular}


Tabel 8. Obat-obat penunjang yang diberikan pada pasien J069

\begin{tabular}{cccc}
\hline Nama Obat & Kegunaan & Jumlah Pasien & Presentase \\
\hline PCT* $^{*}$ & Analgesik & 4 & $100 \%$ \\
Dexametaxone & Kortikosteroid & 4 & $100 \%$ \\
Ambroxol & Mukolitik & 4 & $100 \%$ \\
CTM $^{*}$ & Antihistamin & 3 & $75 \%$ \\
Vitamin C & Vitamin & 3 & $75 \%$ \\
Saleb betametason & Kortikosteroid oles & 1 & $25 \%$ \\
\hline
\end{tabular}

* PCT(Parasetamol); CTM (Chlorpheniramine maleat)

Berdasarkan Tabel 7, dapat dilihat bahwa sebanyak $100 \%$ diberikan amoxicilin sebagai obat terapi, hal ini tidak sesuai dengan teori. Menurut CMA foundation (2007), pengobatan J069 (ISPA tidak spesifik) tidak perlu menggunakan terapi antibiotik dan hanya mengobati gejala. Antibiotika digunakan untuk terapi infeksi bakteri sedangkan untuk J069 tidak dibutuhkan terapi antibiotik karena kemungkinan besar disebabkan oleh virus, sehingga yang diobati adalah gejalanya. Berdasarkan Tabel 8, obat-obatan yang menunjang pengobatan J069 adalah dexametason, CTM, ambroxol dan PCT.

\section{KESIMPULAN}

1. Karakteristik pasien pediatri penderita ISPA di Puskesmas Remaja adalah perempuan $80 \%$, laki-laki $20 \%$, balita $53 \%$, anak-anak $47 \%$, pekerjaan orang tua IRT $73 \%$, pendidikan orang tua SMA sederajat $73 \%$

2. Setiap pasien ISPA pediatri akan diberi 2 terapi yaitu terapi antibiotik dan terapi penunjang.

\section{DAFTAR PUSTAKA}

1. Hood, A., Muhammad, A., Saleh, W.B.M. Taib., 1993, Ilmu Penyakit Paru, Airlangga University Press: Surabaya

2. Zoorob R, Sidani MA, Fremont RD, dan Kihlberg C. 2012. Antibiotic Use in Acute Upper Respiratory Tract Infections. American Family Physician. 86(9): 817-22.

3. Nur, H., 2004. Faktor-Faktor Yang Berhubungan Dengan Kejadian Penyakit ISPA Pada Balita di Kelurahan Pasie Nan Tigo Kecamatan Koto Tangah Kota Padang. Skripsi FKM USU. Medan

4. AJ Brink. 2008. Guidelines for the Management of Upper Respiratory Tract Infections. SA Medical jurnal Vol. 94 No. 6

5. CMA Foundation. 2007. Acute Respiratory Tract Infection Guideline Summary. diunduh dari http://www.nj.gov/health/cd/mrsa/documents/arti_ped_pdf. Diakses pada 6 april 2016.

6. WCDHB. 2013. Antibiotic Guidelines for Primary Care. Diunduh dari http://www.westcoastdhb.org.nz/publications/policies_n_procedures/policies_n_proced ures_docs/inf_ctrl_antibiotic_guidelines_primary/AntibioticGuidelines-Primary.pdf.

Diakses pada 6 april 2016 